\title{
Placing Césaire
}

Some Considerations on Cartography and Enumerative Bibliographies

Alex Gil

\section{(2) OpenEdition}

12 Journals

\section{Electronic version}

URL: https://journals.openedition.org/coma/852

DOI: $10.4000 /$ coma.852

ISSN: 2275-1742

\section{Publisher}

Institut des textes \& manuscrits modernes (ITEM)

\section{Electronic reference}

Alex Gil, "Placing Césaire ", Continents manuscrits [Online], 8| 2017, Online since 15 March 2017, connection on 13 January 2023. URL: http://journals.openedition.org/coma/852 ; DOI: https://doi.org/ 10.4000/coma.852

This text was automatically generated on 13 January 2023

\section{(c) (i) (2) $\Theta$}

Creative Commons - Attribution-NonCommercial-NoDerivatives 4.0 International - CC BY-NC-ND 4.0 https://creativecommons.org/licenses/by-nc-nd/4.0/ 


\section{Placing Césaire}

Some Considerations on Cartography and Enumerative Bibliographies

\section{Alex Gil}

\section{EDITOR'S NOTE}

Cet article est reproduit avec la permission expresse de la revue Caribbean Quarterly (Routledge, Taylor \& Francis Group). Mentions légales : « This permission is limited to nonexclusive print and E-Journal French language rights for this usage only. This permission does not cover any third party copyrighted work which may appear in the material requested. This license does not cover Taylor \& Francis content being republished in a custom publishing program or database. copyright $\odot$ University of the West Indies, reprinted by permission of Taylor \& Francis Ltd, www.tandfonline.com on behalf of University of the West Indies. »

1 Picture the bibliographical prelude: in 1973, Frederick Ivor Case publishes the first enumerative bibliography of Aimé Césaire with the simple title "Aimé Césaire: Bibliographie". Around the same time, we imagine Thomas Hale already hard at work on his thesis, "Aimé Césaire: His Literary and Political Writings with a BioBibliography", which he submits in 1974. A few years later, in 1978, a revised version of the latter is published in a special issue of Études françaises, "Les Écrits d'Aimé Césaire: Bibliographie commentée". Such bibliographic activity in the 1970s announces perhaps more than any other event - the end of Césaire's main writing activity, and the arrival of monumental Césaire.

2 By the end of the 1960s, soon after the publication of Une Tempête, a total of 135 scholarly works had been published on his work. By the end of the 1970s, the number more than doubled to 273. At this point, the total production on Césaire included at least thirty-six monographs, 162 articles and five theses ${ }^{1}$. Césaire was well on his way to being required reading for the aggregation at the École Normale Supérieure - the same aggregation that he himself failed because he was too busy writing. Today, only three years after Kora Véron refined and expanded the work of Thomas Hale in Les Écrits d'Aimé Césaire. Bibliographie commentée (1913-2008) in 2013, we count 1,201 secondary 
works written directly on Césaire ${ }^{2}$. As Hale and Veron's bibliography attests, we also know much more today about Césaire's own writings in print; and with the work of several researchers and archivists in recent years-Jean Jonnaissant, Lilian Pestre de Almeida, Katerina Gonzalez Seligman, Kora Véron, Nadine Albert Ronsin and myself, to name but a few-a genetic dossier is beginning to take shape with the surfacing of rich and important manuscripts.

3 I find it difficult to believe that the bibliographic work started with Césaire's critics in the back pages of their essays and monographs as early as the 1950s, and continuing apace in the publication of these major bibliographies, has not had an impact in the growing research activity around Césaire. What a shame, then, that institutional support for bibliographic work of the enumerative, authorial kind has dwindled in recent decades ${ }^{3}$ and more so at the moment when we need to deploy these modalities for the sake of decolonial, queer, feminist and ecological memory. The internal struggles within bibliographic circles have a role to play in this state of affairs. After all, enumerative bibliography has too often been seen as the poor cousin of analytic and descriptive bibliography by those who should know better ${ }^{4}$. I would argue, though, that the bulk of the blame lies elsewhere.

The more the work of enumerative bibliography is seen as merely "practical" or "technical"-the kiss of death of the hermeneutic class-the further the labour required to compile them shifts into the black boxes of the academy and the private sector. We should leave the deep history of these processes for future work, and content ourselves with a brief outline of the major forces that shape enumerative bibliography today. The most important, by far, is the rise of electronic cataloguing and its back-end indexing, which has come to meet the "information needs" of scholars. These catalogues, both open and private, are accessible today through open and closed networks. Their very material construction traces the history of changing labour relations within and without the academy in recent decades, without losing its connection to a history of indexing that dates to the dawn of human inscription.

With the rise of databases and "discoverability" we see a series of new private industries forming alliances with research and public libraries ${ }^{5}$. In recent years a handful of North Atlantic monopolies-EBSCO, ProQuest, Springer, Wiley-Blackwell and Elsevier, to name a few-have come to dominate the production, flow and "discovery" of the scholarly and pedagogical record in European languages at massive scales. Besides publishing, many of these companies focus on large-scale aggregation and indexing of a host of meso-level operations. Libraries, in turn, have reacted by growing their managerial and IT hierarchies, becoming hesitant middlemen between these companies and scholarly activity. This shift comes as libraries start providing their patrons with information about existing digital literature outside their analog holdings and the bibliographies that accompany them. Besides these closed-access, for-profit industries we see as well the rise of several open-access formations, both legal and contra-legal, that depend on commercial search engines or internal discovery mechanisms specific to each platform.

6 In tandem with these developments, search mechanisms, pressured by Google's lead, have come to operate under certain logics that mark a departure from the hermeneutical loop of traditional enumerative bibliographies. With Google, and its academic avatars, also comes the rise of citation metrics, with its attendant promise of total bibliographies for all active scholars. Who has not yet followed an author link on 
Google Scholar seeking an enumerative bibliography of that author compiled on the fly? And even more prescient, who has not noticed how incomplete and prone to error these systems are? Without a doubt, repetition of the author's sign operates today under black boxes that call for the skills of the bibliographer, the digital humanist and the materialist historian to blast open.

7 To move forward, we must understand enumerative bibliography as a process or set of relations between the author's and the editor's sign, publishing and memory mechanisms, and the long durée of bibliography. This stands in contrast to the metaphors used to describe print bibliographies, which are seen as static, or dead on arrival. On the contrary, while bibliographies are rarely written in stone, their inscription in the scholarly record becomes the harbinger of future repetitions, the supple plasticine of our collective memory.

How then can we think enumerative bibliography given our current digital, financial, labour and legal dispensation? Is a database all we need? What about the crowd? What about the burgeoning genre of the open syllabus? Given current tools, what is to be the relationship between enumerative bibliography and its more exalted forms: the descriptive and the analytical? And more apropos to this essay, what new forms of bibliography are possible once we release the potential of computation and visualisation on enumerative bibliographies under the control of researchers?

\section{The impossible heap}

9 My personal bibliography of Césaire began around ten years ago as a Word document. In those days I knew less than I do now about the destiny of bytes. The work began during early talks of a Digital Library of the Caribbean ${ }^{6}$. During those days, I had also transitioned from a dissertation about certain mythopoetic, mythohistoric themes in Caribbean literature to the very risky, but ultimately more satisfying, single-author dissertation. At this time, I had won a scholarship to spend a séjour at the École Normale in Paris to track the footprints of Césaire's student years. While at the rue d'Ulm, I became interested in la critique génétique and the activities of the Institut des textes et manuscrits modernes (ITEM), which was housed on my floor on the way to the communal showers. While I did not find much to write home about during that first incursion, the bibliography had grown by journey's end to a few hundred entries, both primary and secondary sources.

In 2007, following the breadcrumbs left in the footnotes and works-cited pages of Césaire's critics-far afield into tangential figures in the author s trajectory-I came upon a curious lead in the biography of Ivan Goll: "Enfin dernière lettre de Breton à Goll le 12 décembre 1944 qui réclame cette fois ... le complément des manuscrits de Césaire: Et les chiens se taisaient." (Finally, the last letter from Breton to Goll dated 12 December 1944, asking for the rest of Cesaire's manuscripts: And the dogs were silent.) ${ }^{7}$

11 Aided by a small travel bourse from l'Agence Universitaire de la Francophonie and ITEM, I made my way back to France, to the sleepy town of St Dié des Vosges where, the town lore would have it, America was baptised as such. With the help of Mme Ronsin and other kind librarians at the Bibliothèque Municipale, and using a cheap scanner that I carried in my backpack across the Atlantic, I was able to scan the relevant Césaire documents, without knowing yet what I was scanning. Months later, when I finally found time to study the images, I realised the witness was a hitherto unknown version 
of Et les chiens se taisaient, based on the Haitian Revolution and meant for the theatre ${ }^{8}$. My fate was sealed; this "discovery" channelled my trajectory as a textual scholar, a librarian and a practitioner of the digital arts.

By then, my personal bibliography was beginning to represent one of the few efforts at the time to construct a full bibliography of manuscripts, published works and secondary sources ${ }^{9}$. The range of documents was growing outside the affordances of a simple list on a Word document, so I transferred the list to the more efficient and then young Zotero, "a free, open-source research tool that helps you collect, organise, and analyse research and share it in a variety of ways" ${ }^{10}$. The Zotero database and interface immediately satisfied my needs for organisation, but more importantly, and surprisingly to me at the time, it began to reveal patterns in the bibliography that would blur the lines between interfaces and new knowledge.

During the several years we worked on the critical/genetic edition of (a large portion of) Césaire's works ${ }^{11}$, the bibliography grew to become a resource worth sharing, and worthy of serious attention. In 2013, the same year that the Hale-Veron bibliography was published, at the tail-end of many gatherings in the North Atlantic region in celebration of the centenary of the poet's birth, we organised a two-day event, "Legacies of Césaire", at Columbia University. Taking advantage of the many scholars who were visiting us for the occasion, we planned a day-long bibliographic "researchathon" to precede the conference proper. According to our web announcement ${ }^{12}$,

A researchathon is a collective marathon that seeks either to answer a research question or to build a research resource. This is accomplished by bringing together a group of researchers, librarians, technologists, and students in one room for a full day of collaborative work toward a specific goal. The practice derives from the culture of hackathons familiar to technologists, in which programmers gather for long hours, often late into the night, to solve a software problem collaboratively ... Our researchathon will focus on building the largest existing bibliography of Césaire's primary and secondary sources in one day. At the end of the day we hope to offer our work to present and future researchers of Césaire - open access on the open web. Unlike a print bibliography, ours can continue to update in perpetuity.

14 The researchathon began with a Zotero group created from my personal bibliography, which by then amounted to about 1,600 entries. We divided ourselves into teams. One small team set to work on adding entries from the Hale-Veron bibliography that were still not part of our bibliography. They were able to transcribe a good dozen, or so, pages. The other teams focused on searching for new entries on the networks, closed and open. Our most prolific bibliographer was an undergraduate student, who got right down to business pulling data from JSTOR. By far, the slowest were the researchers invested in Césaire, who would inevitably pause to discuss new findings and needed some extra help with Zotero. The librarians in the room were adept at navigating the vendor-based databases, and had little need for training in Zotero. A fellow librarian from Japan, Jonas Timson, helped us navigate the Japanese national research index, revealing a rich tradition of Césaire studies in that nation. A few researchers joined us from Martinique and France, exploring catalogues familiar to them. By day's end we had a total of 2,200 entries in our shared bibliography.

The process of cleaning the results from the researchathon began a few months after. After de-duplicating and discarding a few hundred false entries, the database stood at close to 2,000 entries. Right now it stands as the richest concentration of secondary 
sources on Césaire in one place, and as we all agreed that day, it is available for use in the Zotero web interface. The work of keying-in Hale-Veron's bibliography continues slowly in the evenings as I wind down from a day's work, but because the latter did not include manuscripts, the open bibliography also stands as the best public record, so far, of Césaire $s$ working papers. The work of revising and adding details within bibliographic entries continues apace as well. Judging from the pace at which I have been able to work on it, a full, open, impossible heap is slated for release by the beginning of next year.

\section{A brief account of Zotero and bibliographic mapping}

With the recent publication of the eighth edition of their Style Guide, the Modem Language Association radically rationalised their bibliographic recommendations to account for the growing number of genres and types of sources for citations. The teamwork that led to these recommendations is to be commended for its keen awareness of the proliferation of media forms in the twenty-first century. Given their attention to our new materialities, I was surprised by the removal of place names from monographs. Perhaps the last thing we need right now is to suggest that documents transcend location. Of course, the decision was surely taken because we do not need place as much anymore to be able to locate texts.

Zotero, though, is not merely a tool for generating citations. Although it does that job extremely well, since the beginning its community of users and contributors have found other uses for the reference management software. The ability to add notes, tags, attachments and related sources to citations announced that the tool's ambitions went beyond simply facilitating the work of creating Works Cited pages. CHNM's early decision to move away from the model of downloading content to manage locally-as Zotero's avatars Scribe and Web Scrapbook had done-and instead operate on the browser, also marked an acknowledgment that "the Web browser had become the location for research"13. This last paradigm shift, and Zotero's ability to read the signs on the wall, is not to be underestimated given our current dispensation. Not only do distribution and access systems today try to meet the reference management software halfway, effectively plying our metadata aspirations; vendors are frantically vying to create controlled research environments linked to content under their control. One only needs to take a look at the vast landscape of self-styled digital humanities projects to notice how we have come to take for granted the combination of analysis and access in the browser.

As far as I can tell, the first attempt to bring mapping functionality to Zotero came with the Zotero Maps plugin developed by Entropy Free LLC and the Zotero project in 2010. While it worked, the tool allowed you to map "any combination of item titles, tags, places of publication, abstracts, and your notes" ${ }^{14}$. Among the early uses that Trevor Owens suggests, we find the following:

Map Places of Publication: In many cases places of publication include crucial information about your items. If you're working on a project involving the history of the book, how different media outlets cover an issue, or how different journals present distinct scientific points of view, the places in which those items are published can provide valuable insight ${ }^{15}$. 
19 Although the tool has not kept up with Zotero's version updates, Zotero Maps and Owens' call effectively pinned to the map of bibliography tools what is now called "The Spatial Turn in the Humanities", not an invention, but "a backwards glance at the reasons why travelers from so many disciplines came to be here, fixated upon landscape, together"16. The idea of mapping document citations, more generally, was already picking up steam on the West Coast when Owens made his suggestion. In a 2009 article, "Visualizing the Republic of Letters" by Daniel Chang and colleagues from Stanford University, we learn that the Republic of Letters project was well underway ${ }^{17}$. In 2012, Dan Edelstein would also begin work on "Voltaire's Places of Publication (1712 -1800)", which fits more clearly within the genre that we could tentatively start calling geo-bibliography.

Owens was also right to call attention to book historians. Many of these, along with manuscript provenance sleuths, had been quick to recognise the value of geospatial tools. A good example of this type of work comes from Mitch Fraas, at the Kislak Center for Special Collections, Rare Books and Manuscripts. Between 2013 and 2014, Fraas gave us a series of wonderful maps on the blog Mapping Books, leveraging the Schoenberg Database of Manuscripts. These maps, tracing the movement of manuscripts and collections, start painting a picture for us of a world of textual materials in motion and settlement, sampling for us the pseudo-Borgesian vision of all actual texts at all times and all places ${ }^{18}$. Footprints: Jewish Books Through Time and Place, a more recent effort of Columbia University and partners, provides us with an example of such wonderful work extended to a dataset with phenomenally enriched metadata ${ }^{19}$.

21 The next powerful mapping tool attached to Zotero - also part of a wave of commendable efforts in the digital humanities to build tools that were easily accessible to the layperson, and to do so adjacent to successful efforts-came in 2012 when Jo Guldi and Cora Johnson-Roberson set out to build "a digital tool that brings a large corpus of historical paper to life"20. The result was Paper Machines, a plugin for Zotero that, among other analytical tools, provides a geoparsing tool. The geoparser generates two visualisations: Flight Paths and a Heatmap. The first one, Flight Paths, "generates a map linking texts from their places of publication to the places they mention, filtered by time." 21 The script can recognise bibliographic entries specified in the Place field. In addition to the citation, the script can also geoparse the content of attachments. Combining these two, the map generated reveals the "flight path" between the location where an item is published and the places it mentions. Like Zotero Maps before it, on the bibliographical side the tool is constrained by the limited number of Zotero database fields, oriented until recent work at the Roy Rosenzweig Center for History and New Media (RRCFFNM) by the desire to produce citation formats ${ }^{22}$. The tool is also geared towards a particular form of interpretation that oscillates between the poetics of place in a given work and the place where that work was declared to have been produced.

As we know, while all texts are produced somewhere-even machine-generated texts coming into being through electronic shifts in molecular structures somewhere-not all citations require "place" to be declared. A scholarly article, to name the most relevant example, does not require a place. One common workaround for those who wanted to declare place (and other extra-citation information) in Zotero was to use the Extra field "hack". The hack consists of using key and values in the field and parsing it using regex. Since the addition of an API, both the hack and the API can be combined to good 
effect. Using this method, for example, geographer Michele Tobias was able to implement a map of Beach Plant Literature for the California Coastal region.

\section{Reading geo-bibliographies: analysis or interface?}

My own approach to mapping our collective Césaire bibliography is similar to Tobias, but without leveraging the API and automating the whole process. The work begins by adding city and country to all entries in the Césaire bibliography in the "Extra" field based on the location of record for a given press for a given document, or barring that, the location of the author at time of publication ${ }^{23}$. Once a set is complete, I export the bibliography as a comma separated values file (CSV). I clean up the data (excess fields, for example) and check for integrity using Google Refine. After the data is clean and the right columns are separated, I import the dataset into CartoDB. One of the current advantages of working with CartoDB is the ability to generate a few useful visualisations out of the box without having to add much code. Below are two early examples based on the complete set of articles, books and theses in the secondary sources folder in our Zotero bibliography ${ }^{24}$.

Map 1, "Aimé Césaire: Secondary Sources by Language" (https://elotroalex.carto.com/ viz/81e2c8c0-d8de-11e5-89c5-0e3ff518bd15/public_map), is a snapshot of an interactive map that separates all secondary sources in our bibliography by language. Clicking on a point brings up the bibliography, straddling the line for us between an enumerative bibliography and a visualisation. Map 1 allows users to display selected languages, and retrieve specific bibliographic information for each pin on the map. The zooming function allows users to expand the number of pins on major metropolitan centres in order to select specific bibliographic items more granularly. The figure shows a citation tooltip visible after clicking on the pin.

Map 1: Aimé Césaire: Secondary Sources by Language

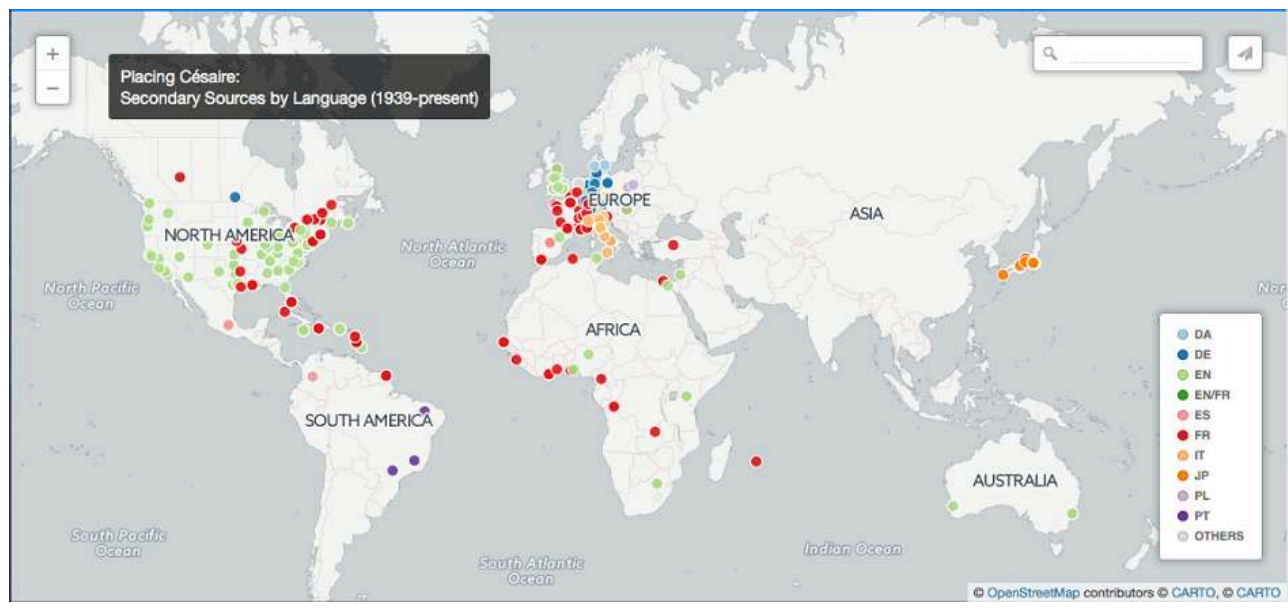

ALEX GIL

Map 2, “Aimé Césaire: Secondary Sources Time Lapse (1939-2016)" (https:// elotroalex.carto.com/viz/7171216a-d8e0-11e5-a6f3-0ecfd53eb7d3/public_map), is a snapshot of an animated clip generated using CartoDB Torque, representing the spread of secondary sources from 1939 until the present in the form of an expanding heat map. Zones of concentration are represented by brighter hues. When the map loads, it 
represents the year 1939. When the user presses play, the map begins moving across time adding publications to the map. By the end, we have reached a full heat map of secondary sources.

Map 2: Aimé Césaire Secondary Sources Time Lapse (1939-2016)

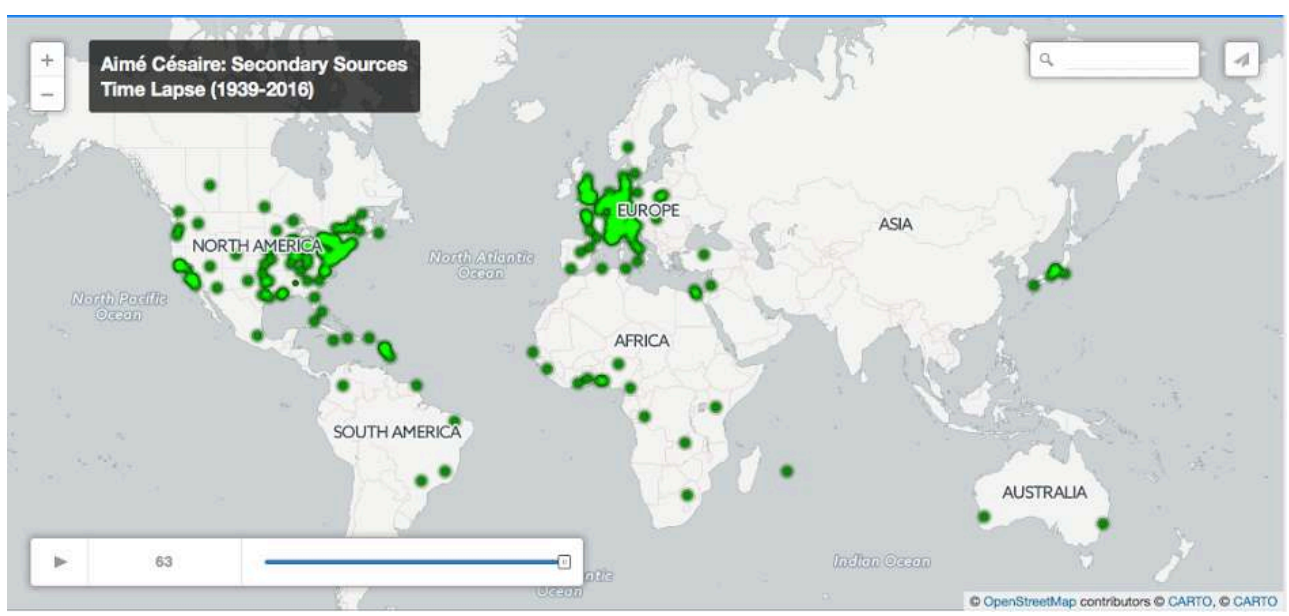

ALEX GIL

A first cursory reading of Maps 1 and 2 suggests certain themes of interest to scholars today: the reception history of Aimé Césaire, outlined in the maps by language and distribution across space and time; the growth of "World Literature" after the war period; a glimpse at négritude publishing in West and Central Africa during the 1960s1980s; the sustained tradition of publishing of and on Césaire in Japan; the absence of secondary sources produced in Eastern Europe, South Asia and East Asia. Each of these themes calls for sustained attention beyond the maps themselves in at least two directions: an expansion of the themes following the carto-bibliographic cues into the archives themselves; and a detailed and honest reckoning of the limits of these bibliographic visualisations to answer questions. We could reframe this question in terms of the tension we experience today when engaging with interactive visualisations between analysis and discovery interface.

Take, for example, the question of reception history. Both figures trace the loci of editorial operations of journals and books that accepted works on Césaire for publication in their venues. Map 1 shows us almost immediately the relative importance of English language scholarship on Césaire compared to French. Immediately after, we begin noticing clusters of activity in German, Japanese and Italian. Finally, we notice the outliers. These relative formations can allow us to make hasty generalisations about the relative importance of Césaire in different parts of the world. Because Map 1 allows us to drill down and get the specific citation for each item, it also becomes a useful tool for further research. Analysis and interface become entangled with each other: the one cannot exist without the other. The questions prompted by the map's inadequate abstractions guide the use of the interface. The same holds for Map 2. Our ability to stop the time-lapse at any moment can give us a picture of the state of scholarship on Césaire at different moments in time since 1939, but it also provides us with a reduced set of prompts for further investigation.

To understand the limits of the visualisation, a reader must always understand the limits of the data model that generated it. In this case, the data itself required me to 
isolate a specific city for each article and book. Each city, and only one city per citation, was chosen as the location where the main headquarters of a journal was indicated historically in the record, inasmuch as that record was accessible. In many cases the city was an assumption based on the headquarters of a journal at another moment in time. Researching each location took me through many discovery portals, closed and open-access: ProQuest; WorldCat; Bibliothèque Nationale de France; Columbia University Libraries, and so on. In a few cases, I had to make assumptions based on the editorial board's main base of operation.

Because we must reduce the production of a text to a single place, at least in this model, we risk losing the location of writing, the byways of distribution, the location of reading and contemporary destinations. Regardless of these gaps, or perhaps because of their visibility, these maps give us a slice of the global system of scholarly production. Such maps open the possibility of modelling through prototypes the location of textual production, distribution and preservation of the scholarly record. While we are forever banned from having the map of all scholarly artefacts, prototyping can serve us well in understanding our limitations and growing our capacity to understand the material life of texts, while at the same time encouraging us to research deeper into the spaces these texts inhabit.

In light of our current dispensation, when we fight for the very transformation and liberation of the scholarly record, such maps will become an indispensable tool in our belt. Such a large-scale operation will inevitably involve different roles inside and outside our institutions. Even though the tension between analysis and interface will likely be taken for granted as visualisations of this kind become more pervasive in the way we understand and interact with the scholarly record, we should also remain attentive to the labour structures they unmask. The recent historical division of labour between researcher (analysis) and librarian (discovery interface) is thrown into stark relief by the location of bibliographic items, even at the moment of its undoing. As new scholarly objects, they become a point of reference for our labour churn. This straddling, perhaps, may be the best way to recuperate for us the central role that enumerative bibliography has in determining our fates as scholar librarians.

\section{NOTES}

1. Many of the works accounted for today were not visible to Césaire's bibliographers at the time. We expect more to surface as our detective work continues.

2. This figure does not count the larger body of work published on the subject of négritude and its continued life.

3. Jerome McGann, A New Republic of Letters: Memory and Scholarship in the Age of Digital Reproduction (Cambridge, Massachusetts: Harvard University Press, 2014).

4. D.W. Krummel, "The Dialectics of Enumerative Bibliography: Observations on the Historical Study of the Practices of Citation and Compilation", Library Quarterly: Information, Community, Policy, 58, no. 3 (July 1988): 238-57. 
5. For examples of the literature, see Anirban Dasgupta et al., "The Discoverability of the Web", Proceedings of the loth International Conférence on World Wide Web (New York: ACM, 2007), 421-30 (accessed 1 June 2016); Mary M. Somerville and Lettie Y. Conrad, "Discoverability Challenges and Collaboration Opportunities within the Scholarly Communications Ecosystem: A SAGE White Paper Update", Collaborative Librarian- ship 5, no. 1 (4 August 2013): 29-41; Yongming Wangand Jia Mi, "Searchability and Discoverability of Library Resources: Federated Search and Beyond", College ér Under- graduateLibraries 19, nos. 2-4 (1 April 2012): 229-45 (accessed 1 June 2016).

6. These early meetings took place in Bellagio, Italy, bringing together an international team of Caribbean researchers and digital humanists from the University of Virginia. At the time, we were working unaware of the team that eventually was able to bring about the Digital Library of the Caribbean that we know today as dLoC: www.dloc.com.

7. Yvan Goll, Situations de l'écrivain: Études réunies par Michel Grunewald et Jean-Marie Valentin (Paris: Lang, 1994), 57-74. The history of the relationship of Goll (1891-1950) to Césaire during the early 1940s can also be richly delineated now through a rich correspondence between Breton, Césaire and others during this period.

8. The rest of that story is told in my article "Découverte de l'Ur-texte de Et les chiens se taisaient", in Aimé Césaire à l'œuvre : actes du colloque international, éd. Marc Cheymol, Philippe OlléLaprune, and A. James Arnold (Paris: Agence universitaire de la francophonie/ITEM: Éditions des archives contemporaines, 2010).

9. Kora Véron, I learned soon enough, was far more advanced in these efforts.

10. See: https://www.zotero.org/about/

11. Albert-James Arnold, éd., Aimé Césaire, Poésie, théâtre, essais et discours (Paris: CNRS, 2014).

12. See: http://cesairelegacies.cdrs.columbia.edu/researchathon/.

13. Daniel J. Cohen, "Creating Scholarly Tools and Resources for the Digital Ecosystem: Building Connections in the Zotero Project", First Monday, Peer-Reviewed Journal on the Internet, 13, no. 5 (4 August 2008), http://firstmonday.org/ojs/index.php/fm/article/view/2233/2017 (accessed 29 June 2016), doi :10.5210/fm.v13i8.2233.

14. Trevor Owens, “Zotero Maps: Visualize Your Zotero Library on the Globe”, Zotero, n.p., 10 May 2010, https://www.zotero.org/blog/zotero-maps-visualize-your-zotero- library-on-the-globe/ (accessed 30 June 2016).

15. Ibid.

16. Jo Guldi, "What Is the Spatial Turn?", Spatial Humanities (Charlottesville: University of Virginia, Scholar's Lab, 2012), http://spatial.scholarslab.org/spatial-turn/ accessed 30 June 2016). See also M.J. Dear, GeoHumanities: Art, History, Text at the Edge of Place (London/New York: Routledge, 2011); Ian N. Gregoryand and Alistair Geddes, Toward Spatial Humanities: Historical GIS and Spatial History (Bloomington: Indiana University Press, 2014); David J. Bodenhamer, John Corrigan, and Trevor M. Harris, eds.. Use Spatial Humanities: GIS and the Future of Humanities Scholarship (Bloomington: Indiana University Press, 2010). The agggregate work of David Wrisley is also relevant here.

17. Daniel Chang, et al., "Visualizing the Republic of Letters", Stanford University http:// web.stanford.edu/group/toolingup/rplviz/papers/Vis_RofL_2009(accessed 1 June 2016).

18. I am consciously postponing the work of location beyond cartographic representations what I mean by map - for another day. One need only remember that call numbers in the spines of books are there to help you locate a book in space, or that the work of citation analysis is there to help you locate a work within a network of relations. For the purposes of this section, though, I am solely interested in thinking through enumerative bibliography directly tied to mundane representations of geographic space.

19. See: https://footprints.ccnmtl.columbia.edu/.

20. "Understanding Paper Machines", Inscape Blog, http://landscape.blogspot.co.uk/2012/03/ understanding-paper-machines.html (accessed 19 March 2012). 
21. See: http://papermachines.org/how-to-use-paper-machines/

22. Version 5.1, slated to be released in 2016, promises to allow users the ability to create their own fields, finally freeing the tool completely from the constraints of the world's citation standards.

23. Secondary sources are all located. I am still in the process of transcribing the entries in the Hale-Véron bibliography to the Zotero bibliography. New entries are keyed in with place indicated.

24. The bibliography itself may exclude many works written on négritude in general, which may have large sections on Césaire. Without perusing all books on the subject, we cannot be certain whether they belong here or not.

\section{AUTHOR}

\section{ALEX GIL}

Columbia University 